\title{
Ecology and evolution of pine life histories
}

\author{
Jon E. Keeley
}

Received: 13 November 2011 / Accepted: 29 February 2012 / Published online: 9 May 2012

(C) The Author(s) 2012. This article is published with open access at Springerlink.com

\begin{abstract}
- Introduction Pinus is a diverse genus of trees widely distributed throughout the Northern Hemisphere. Understanding pine life history is critical to both conservation and fire management.

- Objectives Here I lay out the different pathways of pine life history adaptation and a brief overview of pine evolution and the very significant role that fire has played.

- Results Pinus originated $\sim 150 \mathrm{Ma}$ in the mid-Mesozoic Era and radiated across the northern continent of Laurasia during the Cretaceous Period. Pines have followed two evolutionary strategies interpreted as responses to competition by the newly emerging angiosperms. The Strobus lineage mostly has radiated into stressful sites of low nutrient soils and extremes in cold or heat. The Pinus (subgenus) lineage has radiated into fire-prone landscapes with diverse fire regimes. Examination of life history traits illustrates syndromes associated with fire-avoider, fire-tolerater, fire-embracer, and fire-refuge strategies.

- Conclusion Understanding the current pattern of pine distribution requires interpreting their evolution in terms of climate, geology, and fire. All three of these factors have played a role since the Mesozoic origin of the genus. All are important to the appropriate management of these resources.
\end{abstract}

\section{Handling Editor: Eric Rigolot}

J. E. Keeley $(\bowtie)$

U.S. Geological Survey, Western Ecological Research Center,

Sequoia-Kings Canyon Field Station,

Three Rivers, CA 93271, USA

e-mail: jon_keeley@usgs.gov

\section{J. E. Keeley}

Department of Ecology and Evolutionary Biology,

University of California,

Los Angeles, CA 90095, USA
Keywords Abiotic stress · Cenozoic · Crown fire · Disturbance $\cdot$ Life history $\cdot$ Mesozoic $\cdot$ Surface fire

\section{Introduction}

Pinus is a largely northern hemisphere genus distributed across many forest types in Europe, Asia, North Africa, North America, and Central America. It is a diverse genus of more than 100 species of evergreen sclerophyllous-leaved trees largely restricted to temperate latitudes, or to high elevation temperate conditions at lower latitudes, characteristics shared only by Quercus in the northern hemisphere and Eucalyptus in the southern hemisphere. Unlike the latter two angiosperm genera, which are largely of Cenozoic origin, Pinus is a gymnosperm that originated in the Mesozoic Era (Fig. 1).

Pines trace their origin to the super-continent of Laurasia, and by mid-Cretaceous, they had diverged into two lineages, the Strobus (Haploxylon) and Pinus (Diploxylon) subgenera (Millar 1998). The timing of pine origins and diversification overlaps considerably with angiosperm evolution, and it is likely that competition with these flowering plants played a role in adaptive trajectories taken by pine lineages. In close competition, angiosperms appear to have had several key advantages in both reproductive biology and growth rates (Bond 1989). It is hypothesized that pine evolution reflects competitive exclusion from stable, productive environments by the newly emerging angiosperms.

Life history evolution in pines has taken two pathways that have reduced close competition with fast growing angiosperms. One is an adaptive shift toward abiotically stressful environments, and another is toward fire disturbed environments (Keeley and Zedler 1998). These adaptive modes largely follow the subgeneric split between Strobus and Pinus although there are exceptions (Fig. 2). 


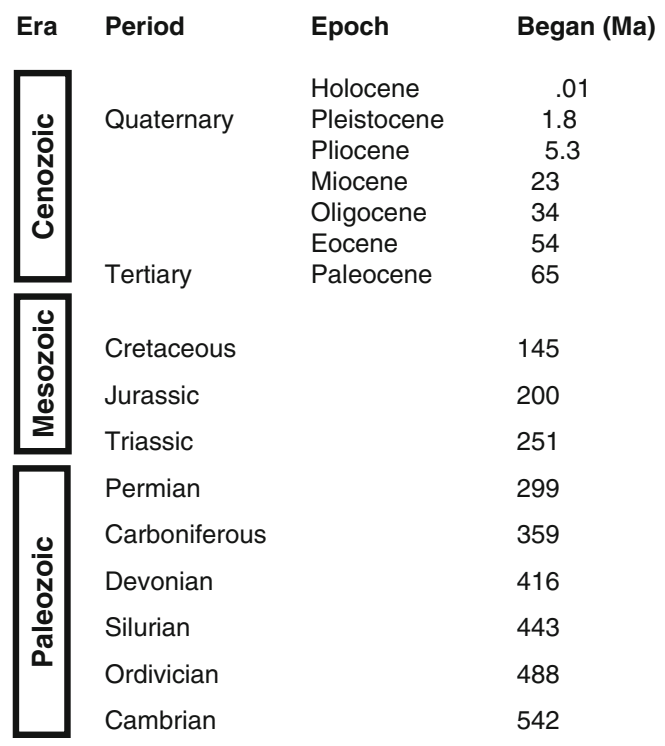

Fig. 1 Geological time scale based on the 2004 time scale endorsed by the International Commission on Stratigraphy (from Keeley et al. 2012)

Most species in the Strobus lineage have radiated into either alpine or desertic environments where growing seasons are relatively short and persistence is challenged by extreme cold or heat. Primary productivity in these environments is generally insufficient to form a contiguous fuel load capable of spreading fire in most years. However, the majority of taxa in the subgenus Pinus are widely distributed on more productive sites that are fire-prone, ranging from environments favoring frequent understory or surface fires to sites subject to less frequent but high intensity crown fires.

\section{Life history evolution}

Life history studies of pines in fire-prone and non-fire-prone landscapes have selected for different character syndromes (Keeley and Zedler 1998), and this is supported by phylogenetic studies that illustrate strong correlations between traits within each subgenus (Schwilk and Ackerly 2001).

\subsection{The fire-avoider pine syndrome}

Alpine Strobus species such as Pinus cembra in Europe or Pinus sibirica in Asia and Pinus albicaulis and Pinus aristata in North America are distributed in environments where fires are not a regular ecosystem feature and these species exhibit few traits that could be interpreted as fire-adaptive traits. In the context of fire, these taxa are here considered fire-avoiders. Additional pines that are not regularly challenged by fires are the pinyon pines in western North America such as Pinus cembroides, Pinus edullis, Pinus monophylla, and Pinus

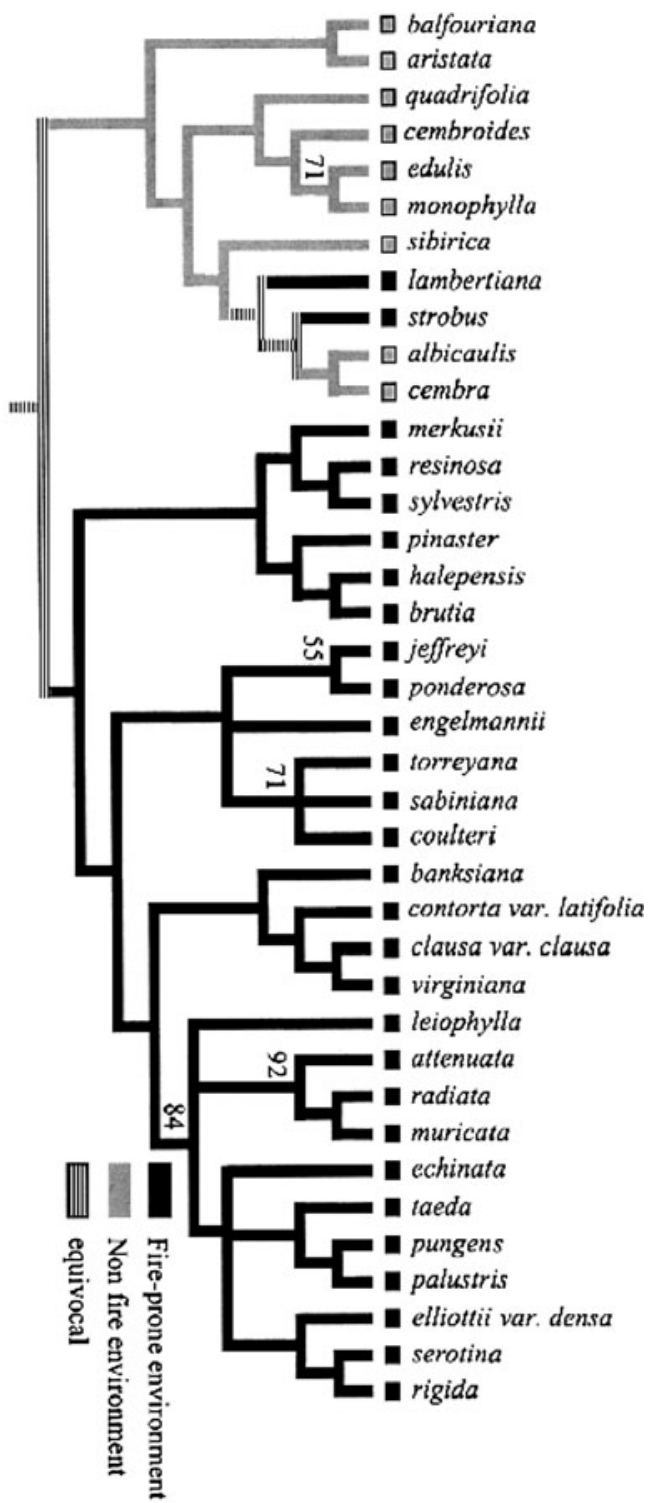

Fig. 2 Phylogenetic distribution of fire-adapted traits in representative pines in subgenera Strobus and Pinus (from Schwilk and Ackerly 2001)

quadrifolia among others in the Strobus lineage that are distributed in desertic environments. These alpine and desertic pines typically have short, densely packed needles that perhaps have been selected for under conditions of extreme heat and cold. These pines uniformly have the thinnest bark in the genus, suggesting that in Pinus bark, thickness is not a response to extreme temperatures but rather, as argued below, to particular fire regimes. In alpine and desertic environments, a key limitation to reproduction is the ability to find safe sites for seedling regeneration, and this may account for why some of these species have indehiscent cones that require birds to open. This coevolved dispersal has resulted in selection for cone characteristics that enhance bird dispersal (Siepielski and 
Benkman 2007), and such dispersal is well developed in these Strobus species but largely unknown in the subgenus Pinus.

\subsection{Fire-adapted pines}

Beginning in the Cretaceous, many pines in the subgenus Pinus followed an adaptive trajectory toward fine-tuning life histories to capitalize on fire-prone landscapes. Regular disturbance from fire diminished the capacity for angiosperms to dominate and favored these pines. However, it is a mistake to think of these pines as adapted to fire, but rather we should think of these species as being adapted to particular fire regimes.

Although no two landscapes have exactly the same fire regime, there is some value in recognizing modal differences (Keeley et al. 2009). Two commonly recognized fire regimes are surface fire regimes and crown fire regimes. Perturbations such as different anthropogenic management practices may move an ecosystem from one fire regime to another, but here I consider the historical or natural fire regime in the absence of human interference.

\subsubsection{Fire-tolerater pine syndrome}

In moderately productive environments, some pines are capable of growth sufficient to maintain their canopies high enough above the forest floor to minimize the possibility of fires burning in surface fuels from carrying into the canopy and killing the tree. Fire scar dendrochronology studies shows that historically these trees were exposed to repeated fires, providing information on past fire frequencies as well as demonstrating that these fires were of sufficiently low intensity that trees survived repeated fires (Fig. 3). Examples of such pines would include Pinus pinea and Pinus pinaster in Europe, Pinus sylvestris throughout many parts of Euro-Asia, and Pinus ponderosa in North America and closely related taxa in Central America.

Survival of these low intensity surface fires is enhanced by several traits. Height is an important attribute and when coupled with self-pruning of dead branches maintains a significant gap between surface fuels and potential canopy fuels (Fig. 4). Thick bark enhances tree survival by protecting sensitive cambial tissue from heat shock (van Mantgem and Schwartz 2003; Bova and Dickinson 2005). Phylogenetic studies indicate a strong correlation between height, self-pruning, and bark thickness in these pines (Schwilk and Ackerly 2001). These firetolerater pines have long needles, which leads to litter with minimal compaction and contributes to high fire intensity, relative to shorter needle species (Fonda et al. 1998). In mixed forests, those sites with higher basal area of pines have significantly greater scorch height due to the greater flame lengths generated from these needles (Knapp and Keeley 2006). It has been hypothesized that pine attributes that increase frequency of fires affect community assembly in ways that favor pines (Platt et al. 1988). Higher temperatures relative to oak litter play a role eliminating reproduction of Quercus seedlings (Williamson and Black 1981); however, patterns of flammability in pine and oak litter are complicated (Kane et al. 2008).

These low intensity surface fire regimes have been branded by Agee (2008) as "nonlethal" fire regimes. While this may be true for the standing timber, it is not a good ecological description of what happens in the understory. For pines and other conifers capable of seedling recruitment in the understory, these surface fires are often lethal to seedlings and saplings (Fig. 5a) and thus successful recruitment requires gaps in the canopy (Fig. 5b). Gaps commonly arise from patches of dense
Fig. 3 a Basal fire scar and b cross section of pine with previous fires delineated. Due to the low intensity surface fires, fire suppression efforts over the last century have been highly successful at nearly eliminating fire from these ecosystems as illustrated by the lack of recent fire scars (photos by J. Keeley)
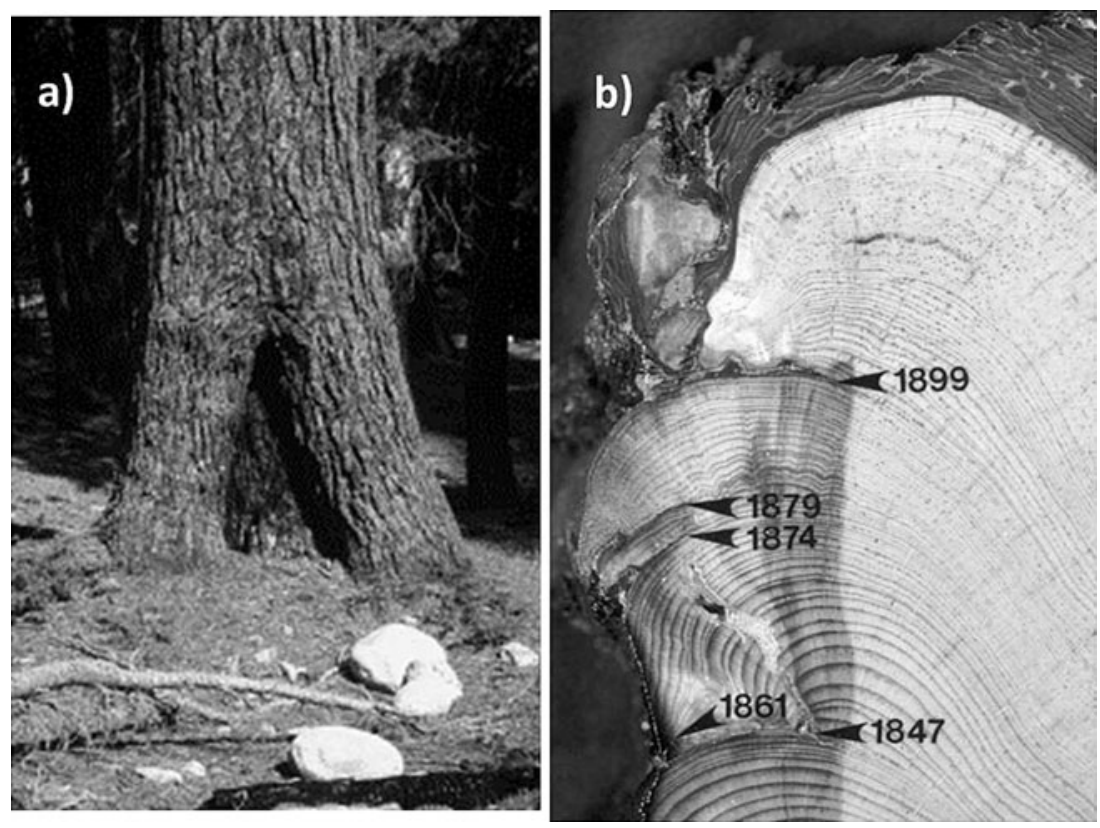
Fig. 4 Examples of firetolerater pines illustrating the self-pruning typical of pines in surface fire regimes: a $P$. pinea from southern France and $\mathbf{b} P$. ponderosa from California (photos by J. Keeley)

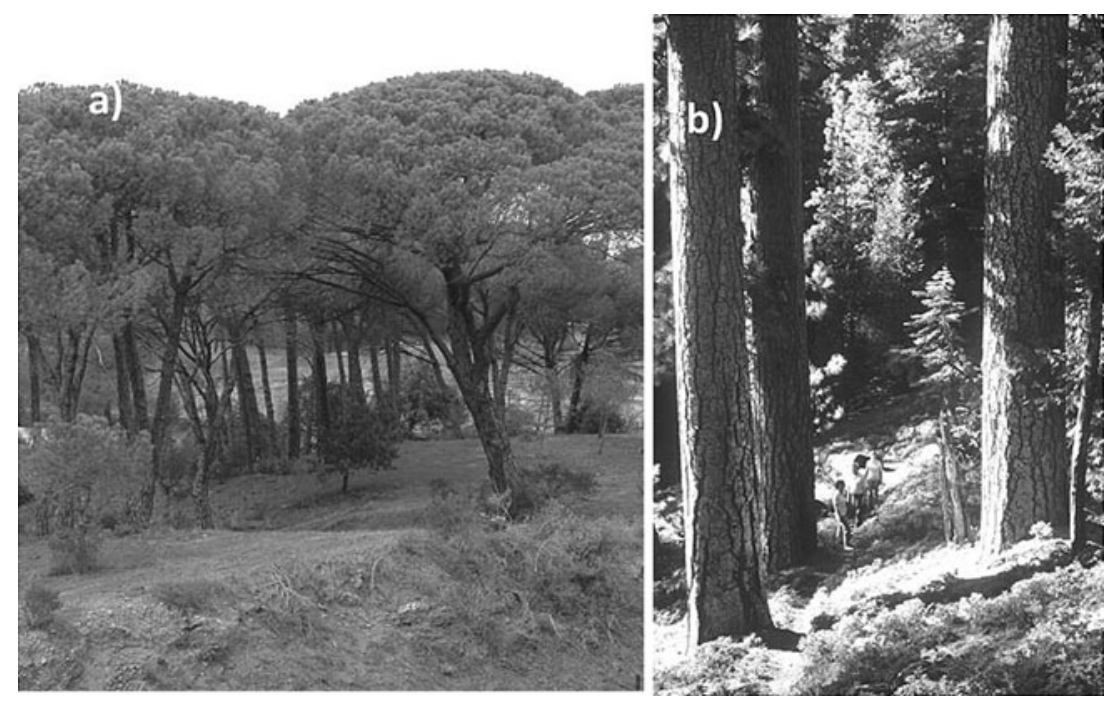

fuels that produce passive crown fires that spread from surface fires into the canopies of small groups of trees. Thus, these pines are ultimately dependent on a mixed fire regime that couples surface fires with localized passive crown fires. Such gaps (Fig. 5b) provide four necessary conditions for successful recruitment: (1) patches of safe sites for recruitment in close proximity to parent seed trees, (2) bare mineral soil that contributes to successful seed germination, (3) high light conditions favoring rapid growth, and (4) limited input of overstory fuels that reduces the probability of repeat fires before the saplings reach an age sufficient to tolerate fire (Keeley and Stephenson 2000).

A few pines have a specialized "seedling grass stage" where the sapling persists as a tuft of needles with little inter-nodal elongation for 5-10 years, during which the needles protect the apical meristem from surface fires (Keeley and Zedler 1998). Eventually the stems bolt and within a few years the sapling canopy is above the reach of surface fires. Due to the vulnerability of the grass stage, this strategy is largely restricted to oligotrophic substrates where fuel loads are relatively low and fire intensities are low. This strategy has been well-studied for Pinus palustris in the southeastern coastal plain of North America but is also known for four others from North America,
Central America, and Southeast Asia. These taxa are distantly related and represent a case of parallel evolution within Pinus (López et al. 2002).

Due to the nature of these low intensity surface fires, on many landscapes, fire managers in both Europe and North America have been highly successful at near total fire exclusion over the past century (e.g., evident in the recent lack of fire scares in Fig. 3b). One consequence of this management practice has been the accumulation of surface fuels and saplings that have put these ecosystems on a trajectory away from surface fires toward crown fires. This has the potential of greatly increasing the size of patches of high intensity burning by orders of magnitude over the historical pattern. This has major impacts on forest regeneration due to the time required for recolonization from standing parent seed trees that could be tens of $\mathrm{km}$ distant from the crown fire gap.

\subsubsection{Fire-embracer pine syndrome}

On less productive sites, pines are unable to grow sufficiently to produce a gap between surface fires and tree canopies (Fig. 6a). In these forests, the natural fire regime is one of
Fig. 5 a Understory of dead ponderosa pine seedlings after surface fire and $\mathbf{b}$ fire-induced gaps with pine regeneration (scale is William Bond in lower left hand corner at $2.1 \mathrm{mht}$; photos by J. Keeley)
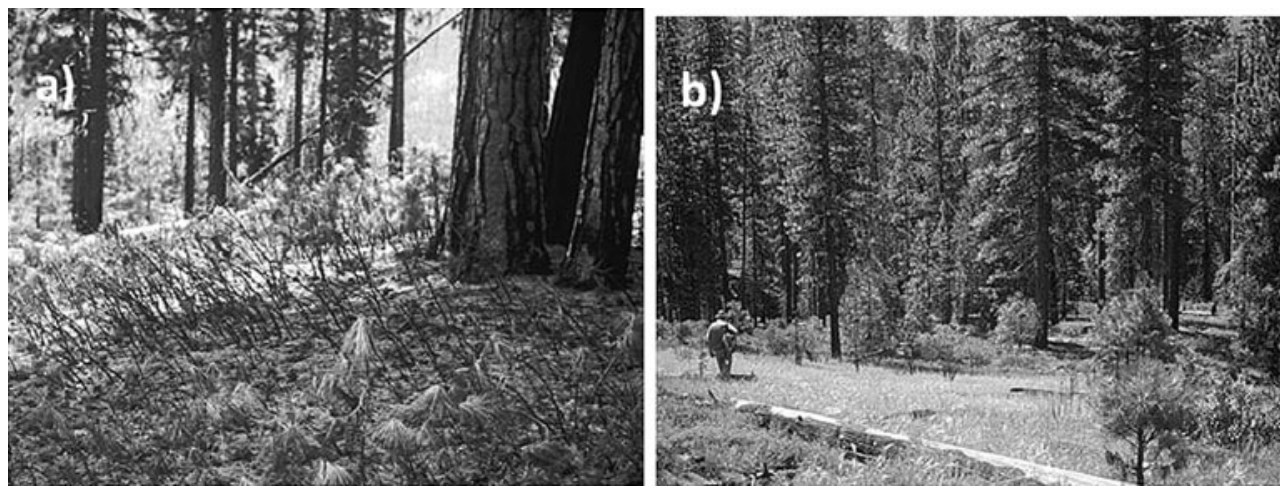

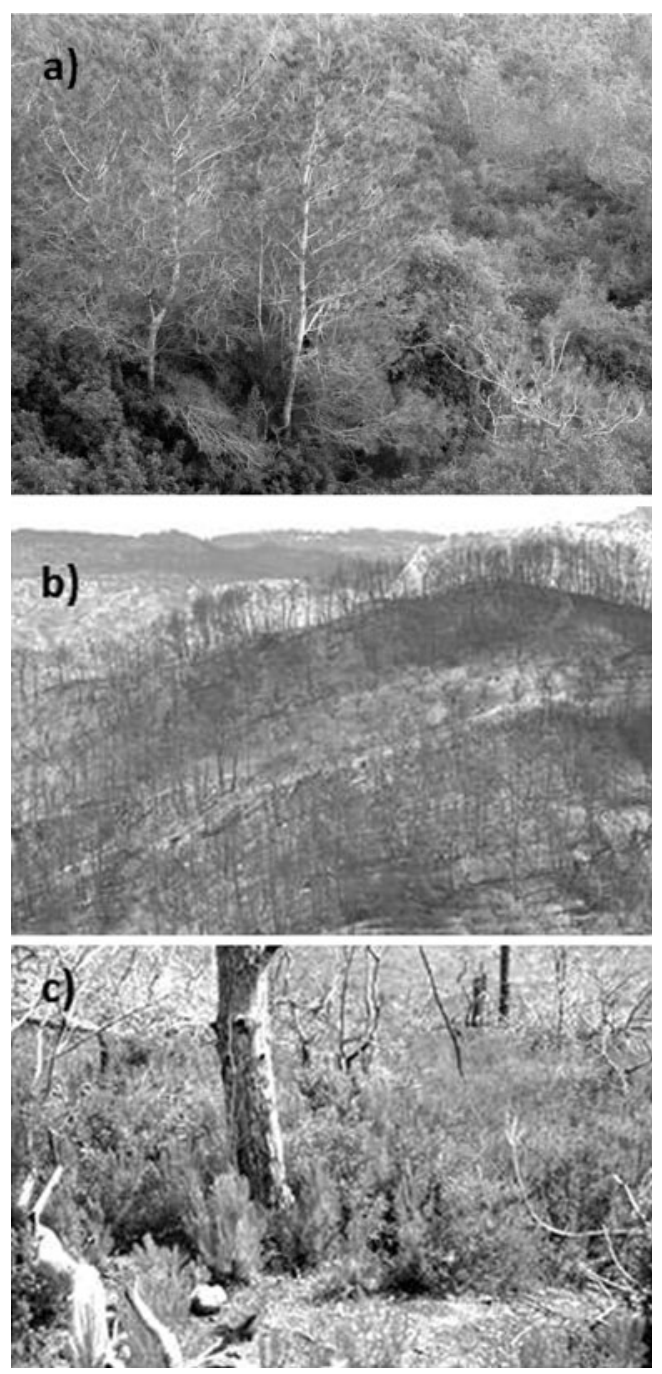

Fig. 6 a $P$. halepensis and associated matorral understory in southern France, $\mathbf{b}$ a typical crown fire in a $P$. halepensis forest; 2007 fire in Greece, and $\mathbf{c}$ postfire recruitment of $P$. halepensis seedlings after 1989 fire on Mt. Carmel, Israel (photos by J. Keeley)

intense crown fires such as observed in the Mediterranean Pinus halepensis and Pinus brutia forests (Fig. 6b), or high latitude North American Pinus contorta forests and boreal Pinus banksiana forests, or California chaparral Pinus attenuata, to name just a few (Keeley and Zedler 1998). Rather than merely tolerating fire, these pines embrace fire by both enhancing the capacity for fires to consume tree canopies as well as delaying reproduction to a single postfire pulse of recruitment from serotinous cones (Fig. 6c) (e.g., Anderson and Romme 1991; Ne'eman and Izhaki 1998). Serotiny, however, carries a cost in that maintaining an aerial seed bank for extended periods of time puts those seeds at risk for predation. Thus, it is no surprise that cone characteristics have been shaped by seed predators, and this has had impacts on genetic patterns in some species (Parchman et al. 2011).
These fire-embracers enhance the spread of fire by limited self-pruning of dead branches, which increases ladder fuels capable of carrying fire into the canopy and ensuring crown fire. Retention of dead branches in the canopy of species in crown fire ecosystems has a measurable impact on fire intensity (Schwilk 2003). This enhances both the opening of cones as well as ensuring fire spread to adjacent canopies and thus opening the site for better recruitment. Regeneration is achieved by fire-stimulated opening of serotinous cones and synchronous seed dispersal in a single postfire pulse. Needles tend to be shorter than in firetolerater species and have burning characteristics that promote longer duration burning (Fonda 2001). Illustrative of the fine-tuning of evolution is the fact that these pines generally have much thinner bark than fire-toleraters, which likely reflects the limited effectiveness of thick bark in a crown fire regime. This is a common theme as illustrated by Quercus trees adapted to surface fires vs shrubby oak species adapted to crown fires; the former have thick bark and the latter very thin bark (Zedler 1995a, b).

\subsubsection{Fire-refugia pine syndrome}

Some pines on fire-prone landscapes seem to fit neither of these syndromes. For example, in California, there are pines such as Pinus sabiniana with relatively thick bark but limited self-pruning of lower branches. This species is widespread in chaparral and grasslands, and in the former habitat, it inevitably succumbs to chaparral crown fires yet it generally lacks cone serotiny and thus fails to regenerate on the site of such conflagrations. However, it survives well in grasslands, rock outcrops, riparian zones, or other sites with sparse fuels. Large crown fires may extirpate this species over broad areas, and it shrinks to a few localized refugia. In subsequent years, trees disperse out from these refugia into vegetation where they may persist for decades (Schwilk and Keeley 2006).

Thus, this fire-refugia species exhibits marked population fluctuations driven by metapopulation dynamics where refugia populations act as sources for expansion after fire. This is in marked contrast with the other two fire related pine syndromes in which population perimeters are relatively static overtime, although in these other syndromes occasional outlier trees may establish new populations (Harvey et al. 2011).

\subsubsection{Temporal and spatial variation in pine life history}

Evidence of the importance of fire regime in driving life history characteristics is illustrated by widespread species that persist under multiple fire regimes and exhibit population differentiation consistent with fire regime differences. For example, the Californian Pinus coulteri exhibits fire- 
embracer traits of limited self-pruning and serotiny in chaparral crown fire environments but is non-serotinous in woodlands with surface fires, and this pattern is found in other serotinous species (Keeley and Zedler 1998).

Fire regimes are a function of multiple parameters that vary continuously in both time and space, and this variation is often reflected in life history variation. For example, the Canary Island pine, Pinus canarensis, exhibits extraordinary trait variation across a broad spectrum of fire regimes where predictable crown fires apparently have selected for fire-embracer traits such as serotiny and resprouting on some sites and firetolerater characteristics on other sites (Climent et al. 2004). The North American P. contorta is distributed across a broad spectrum of environments such that it ranges from sub-alpine fire-avoider populations, to fire-tolerater populations in the Sierra Nevada of California, to serotinous fire-embracer populations in the Rocky Mountains of Montana (Critchfield 1957). These regional differences are tied to climatic differences that affect site productivity and thus propensity for crown fires (Parker 1986).

\section{Evolution of fire-adapted pines}

Broadly speaking, we can divide pine evolution into three stages: (1) Mesozoic origin and diversification, (2) the early Cenozoic fragmentation due to angiosperm dominance under the equable climates of the Eocene, and (3) Oligocene and Miocene diversification due to expansion of fire-prone and abiotically stressful habitats. Discussions of pine evolution have focused almost entirely on the role of climate and geology and their effect on migration pathways, refugia, and population isolation (Axelrod 1986; Millar 1998). Here I stress that these factors drove two separate evolutionary trajectories. One lineage followed a pathway of adaptation to biotically stressful conditions promoted by extreme temperatures and highly oligotrophic soils. Evolution along the other pathway was driven by fire adaptations closely tuned to differences in site productivity and fuel structure that generated different fire regimes and very different fire-adaptive traits.

\subsection{Mesozoic origin and diversification}

Pinaceae dates to the early Mesozoic and the genus Pinus perhaps mid-Jurassic (Axelrod 1986; Millar 1998). The earliest fossil record of Pinus is Early Cretaceous, $130 \mathrm{Ma}$ (Millar 1998), and molecular phylogenetic estimates provide a wide range of estimates between 102 and $190 \mathrm{Ma}$ (Willyard et al. 2007). A Jurassic origin is supported by the relatively high diversity of Pinus already present in the Cretaceous.

Early pine evolution was concentrated between $31^{\circ}$ and $50^{\circ}$ in the Northern Hemisphere on the Laurasian super- continent. During this period, pines radiated widely, and by the end of the Cretaceous, they were distributed in the west from what is presently North America to the east on the present day continent of Asia. By this time, they had already diverged into lineages that subsequently spread to North America and to Euro-Asia (López et al. 2002; Gernandt et al. 2008). During this period, temperature and rainfall exhibited little seasonality at these latitudes (Wolfe and Upchurch 1987), and pine success is thought to have been driven by the limited dominance of angiosperms (Millar 1998).

By the mid-Cretaceous, both the fossil record (Millar 1998) and molecular phylogenies (Willyard et al. 2007; He et al. 2012) show Pinus split into subgenera Strobus and Pinus. These have largely followed very different adaptive trajectories: the former subgenus to abiotically stressful conditions and the latter into fire-prone landscapes. Functional trait analysis in pines shows that thick bark is always associated with fireadapted pines with fire-tolerater strategies and lacking in species adapted to stresses of extreme cold or aridity or to crown fire regimes (Keeley and Zedler 1998). Ancestral trait reconstruction supports a Cretaceous origin for this trait, strongly implying that fire adaptation was already an important driver of pine evolution at this time (He et al. 2012). Angiosperms at this time were rapidly diversifying into mostly fast growing weedy species (Wing and Boucher 1998), and it is possible this contributed to fuel continuity that enhanced fire spread (Bond and Scott 2010).

A growing body of fossil data shows that throughout the Paleozoic and Mesozoic eras, fire was widely distributed in space and time and numerous lines of evidence indicate that it was a potentially important ecosystem process (Pausas and Keeley 2009). There is also evidence that different fire regimes were selecting for fire-tolerater and fire-embracer strategies. Perhaps reflective of these early differences are the Californian genera Sequoia and Sequoiadendron. Both are of Mesozoic origin and the former is a vigorous resprouter adapted to infrequent crown fires, and the latter is a non-resprouter but tolerates frequent fires due its extremely thick bark and self-pruning (Keeley et al. 2012).

Although climates of the Cretaceous are often characterized as lacking seasonal droughts, decadal scale droughts would have made landscapes fire-prone as is true of many aseasonal climatic regions today. Although these distant Cretaceous landscapes are often discussed as though they were homogenous, landscapes did exhibit topographic heterogeneity and coastal and interior climates added to this heterogeneity (Mix et al. 2011). Indeed, at higher latitudes, freezing temperatures would have selected for evergreen sclerophylls (Spicer et al. 1993) and would have been an impetus for evolution of stress tolerating pines typical of the Strobus lineage. Semi-arid fire-prone landscapes were not lacking at middle and lower latitudes (Spicer et al. 1993). 
As is the case today, small changes in climate would have affected site productivity in ways that could profoundly alter fire regimes (Rehfeldt et al. 1999) and play an important role in driving pine evolution. Today most species in the subgenus Pinus exhibit life histories very closely tied to fire, and there is little reason to not accept that Cretaceous radiation of pines was driven in large part by fire. Indeed, splits between subsection Contortae, dominated by fire-embracers, and Ponderosae, dominated by fire-toleraters, date to the Cretaceous (López et al. 2002). Some Cretaceous landscapes have been described as dominated by fire-adapted "chaparral-like shrublands" (conifers, cycads, ferns) that supported diverse dinosaur faunas and with abundant evidence of periodic fires. Allen (1998) interpreted many charred fossil remains from these sites as fire adaptations, including serotinous cones, firestimulated hard seeds, and highly sclerotic fern indusia dropped when heated by fire.

\subsection{Early Cenozoic fragmentation under the equable climates of the Eocene}

The warm, aseasonal climates of the Eocene led to tropical angiosperm dominance that displaced pines from middle to high latitudes where they previously had dominated (Millar 1998). The widespread extirpation of middle latitude pines at the beginning of the Cenozoic is hypothesized to have led to extinction of many species and depleted genetic diversity. Many Cretaceous fossil pines with combinations of traits not known in extant species went extinct (Millar 1998). Based on the fossil record, this was a period of fragmentation in pine populations and apparently limited pine diversification (Millar 1993).

The rise in highly productive angiosperm forests is thought to have greatly diminished fire activity during the Eocene (Bond and Scott 2010). However, this conclusion is based on temporal changes in the distribution of the charcoal inertinite laid down in moist mire habitats. In the Cretaceous, these mires were highly fire-prone habitats, but the inertinite signal declines with the Eocene dominance of such sites by tropical angiosperm forests, suggesting to these authors that early Cenozoic fires were relatively rare. However, this inertinite signal need not be interpreted as evidence for lack of Eocene fire. I hypothesize that fireprone habitats shifted to more drought-prone upland sites, promoted in large part by the rapid diversification of fast growing drought-adapted angiosperms that provided fuel to carry fires far beyond the apparently limited fire-prone landscape of the Mesozoic. Indeed, on contemporary landscapes, mires, and the inertinite fire signal, comprise only a few percent of the land surface compared to contemporary fire-prone environments that occupy over half of the land surface (Krawchuk et al. 2009). Fossil evidence for such fire-prone Eocene sites is not very plentiful, but then fossil records throughout both the Tertiary and Quaternary are highly biased against recording upland fire-prone vegetation (Keeley et al. 2012).

Although the equable climates of the Eocene make it appear as though this world was not highly conducive to fires, this is something of an artifact since climatic oscillations on multiple time scales are permanent features of earth history (Bennett 2004). In addition to temporal variation, there was spatial variation as evident by precipitation gradients that generated dry seasons in parts of southwestern North America (Frederiksen 1991) with a clear potential for a predictable wildfire season (Keeley et al. 2012). Dry zones at this time along the European and North African Tethys (Parrish 1998) may have favored fire-prone pines. Much of the Eocene world may not have been conducive to fire-dependent pine evolution, but it is unknown what was transpiring along the more arid fringes and as a consequence of anomalous climatic events. That pine evolution continued is supported by molecular phylogenies, which show, in contrast to the apparent contraction and limited evolution of pines implied by the fossil record, that there was very little change in diversification rates during the Eocene Epoch (Eckert and Hall 2006).

\subsection{Oligocene and Miocene diversification}

The end of the Eocene was associated with a rapid drop of 10$14^{\circ} \mathrm{C}$ and increased aridity in the Oligocene, causing the loss of tropical angiosperm forests across middle latitudes, all of which contributed to the expansion of pines back into latitudes where they once dominated (Millar 1998). These changes would have had an immediate impact on the radiation of those pines adapted to abiotically extreme cold and aridity. In addition, with a change to more seasonal conditions, changes in fire regimes would have followed. Although it is hypothesized that Eocene fires were spatially limited to arid margins and drought-prone substrates, or temporally limited to anomalously dry years, the Oligocene expanded both the spatial and temporal distribution of fire-prone landscapes. Thus, patches of fire-prone landscape once isolated by more mesic vegetation were now connected with greater fuel continuity and thus greater predictability of fires.

Increased seasonality characterized the Miocene thus creating greater opportunities for exploiting new fire regimes, and this was likely an important driver of the high pine speciation rates observed during this epoch (Willyard et al. 2007). This model is supported by phylogenetic data indicating that taxa typical of surface fire regimes gave rise to new lineages of crown fire-adapted pines and vice versa. For example, the Miocene origin of serotinous fire-embracers in subsection Attenuatae appears to derive from fire-tolerater ancestors (López et al. 2002). Another example would be the apparent derivation of the fire-tolerater Pinus lambertiana from the fire-avoider $P$. albicaulis (Liston et al. 2007). 
Axelrod (1988) contended that by late Miocene, many closed-cone pines dominated large portions of semi-arid landscape but with the Quaternary intensification of summer drought were restricted to islands of more mesic habitat. Alternatively, Millar (1999) has hypothesized that contemporary disjunct populations are not the result of contraction of a broader distribution but a metapopulation pattern that persisted through the Quaternary and was the result of anomalous climate fluctuations that caused populations to expand and shrink. Millar's model could also work for very different reasons. With these fire-adapted species, subtle spatial and temporal variations would have produced a mosaic of fire regimes and selected for different suites of species in a fine-grained distribution pattern, generating a patchy distribution of pine species.

\section{Conclusions}

Pine evolution has always been interpreted in terms of climate and geology. I propose that one must understand the role of fire to adequately interpret the patterns of diversification in this genus. Contemporary pines have diverged into species that favor abiotically stressful sites or ones that favor more productive sites subject to regular and predictable fires. Associated with these different environmental stresses are a suite of plant traits that are interpreted as character syndromes in response to different environments. The majority of species are fire-adapted, but it is useful to keep in mind that species do not adapt to fire per se, but rather to a particular fire regime. Several syndromes are described that are associated with different fire regimes. The presence of high fire activity in the Mesozoic and the phylogenetic analyses that show fireadaptive traits can be traced to this era support the conclusion that the evolution of pines is best understood in terms of fire and abiotic stresses as driving trajectories of life history adaptation in pine evolution.

Acknowledgments I thank the organizers of the MEDPINE4 conference for the invitation to present this keynote address. This work was funded by the U.S. Geological Survey and the MEDPINE4 Conference.

Open Access This article is distributed under the terms of the Creative Commons Attribution License which permits any use, distribution, and reproduction in any medium, provided the original author(s) and the source are credited.

\section{References}

Agee JK (2008) The fallacy of passive management. Conserv Mag 3 [no pagination]

Allen P (1998) Purbeck-Wealden (early Cretaceous) climates. Proc Geol Assoc 109:197-236
Anderson JE, Romme WH (1991) Initial floristics in lodgepole pine (Pinus contorta) forests following the 1988 Yellowstone fires. Int J Wild Fire 1:119-124

Axelrod DI (1986) Cenozoic history of some western American pines. Ann Mo Bot Gard 73:565-641

Axelrod DI (1988) Paleoecology of late Pleistocene Monterey pine at Laguna Niguel, southern California. Botanical Gazette 149:458464

Bennett KD (2004) Continuing the debate on the role of Quaternary environmental change for macroevolution. Philosophical Transactions of the Royal Society of London, B, 359:295303

Bond WJ (1989) The tortoise and the hare: ecology of angiosperm dominance and gymnosperm persistence. Biol J Linn Soc 36:227249

Bond WJ, Scott AC (2010) Fire and the spread of flowering plants in the Cretaceous. New Phytol 188:1137-1150

Bova AS, Dickinson MB (2005) Linking surface-fire behavior, stem heating, and tissue necrosis. Can J For Res 35:814-822

Climent J, Tapias R, Ja P, Gil L (2004) Fire adaptations in the Canary Islands pine (Pinus canariensis). Plant Ecol 171:185-196

Critchfield WB (1957) Geographic variation in Pinus contorta. Harvard University, Cambridge

Eckert AJ, Hall BD (2006) Phylogeny, historical biogeography, and patterns of diversification for Pinus (Pinaceae): phylogenetic tests of fossil-based hypotheses. Mol Phylogenet Evol 40:166-182

Fonda RW (2001) Burning characteristics of needles from eight pine species. For Sci 27:390-396

Fonda RW, Belanger LA, Burley LL (1998) Burning characteristics of western conifer needles. Northwest Sci 72:1-9

Frederiksen NO (1991) Pulses of middle Eocene to earliest Oligocene climatic deterioration in southern California and the Gulf Coast. Palaios 6:564-571

Gernandt DS, Magallón S, López GG, Flores OZ, Willyard A, Liston A (2008) Use of simultaneous analyses to guide fossil-based calibrations of Pinaceae phylogeny. Int J Plant Sci 169:10861099

Harvey BJ, Holzman BA, Davis JD (2011) Spatial variability in stand structure and density-dependent mortality in newly established post-fire stands of a California closed-cone pine forest. For Ecol Manag 262:2042-2051

He T, Pausas JG, Belcher CM, Schwilk DW, Lamont BB (2012) Fireadapted traits of Pinus arose in the highly flammable Cretaceous. New Phytol. doi:10.1111/j.1469-8137.2012.04079.x

Kane JM, Varner JM, Hiers JK (2008) The burning characteristics of southeastern oaks: discriminating fire facilitators from fire impeders. For Ecol Manag 256:2039-2045

Keeley JE, Stephenson NL (2000) Restoring natural fire regimes to the Sierra-Nevada in an era of global change. In: Wilderness science in a time of change conference-volume 5: wilderness ecosystems, threats, and management; 1999 May 23-27, vol 5. US Department of Agriculture, Forest Service, Rocky Mountain Research Station, Missoula, pp 255-263

Keeley JE, Zedler PH (1998) Evolution of life histories in Pinus. In: Richardson DM (ed) Ecology and biogeography of Pinus. Cambridge University Press, Cambridge, pp 219-250

Keeley JE et al (2009) Ecological foundations for fire management in North American forest and shrubland ecosystems, vol. General Technical Report, PNW-GTR-779. USDA Forest Service, Pacific Northwest Research Station, Portland, p 92

Keeley JE, Bond WJ, Bradstock RA, Pausas JG, Rundel PW (2012) Fire in Mediterranean ecosystems. Ecology, evolution and management. Cambridge University Press, Cambridge

Knapp EE, Keeley JE (2006) Heterogeneity in fire severity within early season and late season prescribed burns in a mixed conifer forest. Int J Wild Fire 15:1-9 
Krawchuk MA, Moritz MA, Parisien M-A, Dorn JV, Hayhoe K (2009) Global pyrogeography: the current and future distribution of wildfire. PLoS One 4:e5102

Liston A, Parker-Defeniks M, Syring JV, Willyard A, Cronn R (2007) Interspecific phylogenetic analysis enhances intraspecific phylogeographical inference: a case study in Pinus lambertiana. Mol Ecol 16:3926-3937

López GG, Kamiya K, Harada K (2002) Phylogenetic relationships of Diploxylon pines (subgenus Pinus) based on plastid sequence data. Int J Plant Sci 163:737-747

Millar CI (1993) Impact of the Eocene on the evolution of Pinus L. Ann Mo Bot Gard 80:471-498

Millar CI (1998) Early evolution of pines. In: Richardson DM (ed) Ecology and biogeography of Pinus. Cambridge University Press, Cambridge, pp 69-91

Millar CI (1999) Evolution and biogeography of Pinus radiata, with a proposed revision of its Quaternary history. N Z J For Sci 29:335-365

Mix HT, Mulch A, Kent-Corson ML, Chamberlain CP (2011) Cenozoic migration of topography in North American cordillera. Geology 39:87-90

Ne'eman G, Izhaki I (1998) Stability of pre- and post-fire spatial structure of pine trees in Aleppo pine forest. Ecography 21:535-542

Parchman TL, Benkman CW, Jenkins B, Buerkle CA (2011) Low levels of population genetic structure in Pinus contorta (Pinaceae) across a geographic mosaic of co-evolution. Am J Bot 98:669-679

Parker AJ (1986) Persistence of lodgepole pine forests in the central Sierra Nevada. Ecology 67:1560-1567

Parrish JT (1998) Interpreting pre-Quaternary climate from the geologic record. Columbia University Press, New York, New York

Pausas JG, Keeley JE (2009) A burning story: the role of fire in the history of life. BioScience 59:593-601

Platt WJ, Evans GW, Rathbun SJ (1988) The population dynamics of a long-lived confer (Pinus palustris). Am Nat 131:491-525

Rehfeldt GE, Ying CC, Spittlehouse DL, Hamilton DA Jr (1999) Genetic responses to climate in Pinus contorta: nice breadth, climate change, and reforestation. Ecol Monogr 69:375-407
Schwilk DW (2003) Flammability is a niche construction trait: canopy architecture affects fire intensity. Am Nat 162:725733

Schwilk DW, Ackerly DD (2001) Flammability and serotiny as strategies: correlated evolution in pines. Oikos 94:326-336

Schwilk DW, Keeley JE (2006) The role of fire refugia in the distribution of Pinus sabiniana (Pinaceae) in the southern Sierra Nevada. Madrono 53:364-372

Siepielski AM, Benkman CW (2007) Convergent patterns in the selection mosaic for two North American bird-dispersed pines. Ecol Monogr 77:203-220

Spicer RA, Rees PM, Chapman JL (1993) Cretaceous phytogeography and climate signals. Philos Trans R Soc Lond B 341:277-286

van Mantgem P, Schwartz M (2003) Bark heat resistance of small trees in Californian mixed conifer forests: testing some model assumptions. For Ecol Manag 178:341-352

Williamson GB, Black EM (1981) High temperature of forest fires under pines as a selective advantage over oaks. Nature 293:643644

Willyard A, Syring J, Gernandt DS, Liston A, Cronn R (2007) Fossil calibration of molecular divergence infers a moderate mutation rate and recent radiations for Pinus. Mol Biol Evol 24:90-101

Wing SL, Boucher LD (1998) Ecological aspects of the Cretaceous flowering plant radiation. Ann Rev Earth Plant Sci 26:379421

Wolfe JA, Upchurch GR Jr (1987) North American nonmarine climates and vegetation during the Late Cretaceous. Palaeogeogr Palaeoclimatol Palaeoecol 61:33-77

Zedler PH (1995a) Are some plants born to burn? Trends Ecol Evol 10:393-395

Zedler PH (1995b) Fire frequency in southern California shrublands: biological effects and management options. In: Keeley JE, Scott T (eds) Brushfires in California: ecology and resource management. International Association of Wildland Fire, Fairfield, pp 101-112 